\title{
FILSAFAT ISLAM KLASIK DAN PERKEMBANGAN ILMU PENGETAHUAN MODERN DI EROPA
}

\author{
Ibrahim \\ Dosen Bidang Filsafat Islam \\ Fakultas Ushuluddin, Filsafat dan Politik \\ UIN Alauddin Makassar
}

\begin{abstract}
Abstrak
Artikel ini membahas mengenai spirit pencarian dan penyebaran ilmu pengetahuan dalam Islam yang telah ditunjukkan dengan menarik oleh para tokoh dalam masa klasik. Dilakukan penerjemahan, penulisan kembali, penyalinan kitab-kitab dari Bahasa Yunani ke bahasa arab ataupun Persia di dunia Islam. Artikel ini ingin menunjukkan bahwa ilmu pengetahuan saat ini dan juga tentunya filsafat secara luas menyimpan jasa peradaban muslim di dalamnya dalam hal mempercepat transmisi pemikiran klasik ke dalam pemikirn dunia modern. Dengan metode penelusuran literatur, artikel ini berhasil menemukan bahwa Islam memiliki peran signifikan dalam 'pembentukan' ilmu pengetahuan modern saat ini.
\end{abstract}

\section{Keywords: \\ Islam Klasik, Pemikiran, Modern}

\section{PENGANTAR}

Tak ada kata yang lebih utama disebutkan oleh Al-Qur'an, kitab suci umat Islam, selain kata ilm'. Ilmu adalah kata kunci yang amat kuat tertanam dalam tradisi Islam. Dalam catatan Siauddin Zardar "Alquran menggunakan kata ' $\mathrm{ilm}$ lebih dari 800 kali, meluangkan sekitar sepertiga dari kandungannya untuk memuji gagasan-gagasan seperti akal, perenungan, penelitian, pengkajian, kesarjanaan, perjalanan (mencari 'ilm) - yang semuanya pada akhirnya bergantung pada semacam komunikasi. Dalam beberapa kasus, dorongan Alquran bersifat umum, seperti "ya Tuhanku, tambahkanlah kepadaku ilmu pengetahuan (Q.S. Thaha: 14); "sesungguhnya pada langit dan bumi benar-benar terdapat tanda-tanda (kekuasaan Allah) bagi orang-orang yang beriman (Q.S. al-Jatsiyah:3); dan berjalanlah di muka bumi, maka perhatikanlah bagaimana Allah menciptakan (manusia) dari permulaannya, kemudian Allah menjadikannya sekali lagi. Sesungguhnya Allah maha kuasa atas segala sesuatu (Q.S. al-Ankabut:20). Dalam kasus lainnya Alquran memberi perintah yang spesifik. Ia mengatakan kepada para penulis agar mereka, "tidak enggan menuliskannya" (Q.S. al-baqarah:282), karena jika tidak, maka hal itu berarti penolakan terhadap anugrah Tuhan yang diberikan kepada mereka"1.

Sejak awal, ayat-ayat pertama yang diturunkan sebagai perintah Allah kepada Muhammad Saw di bukit Hira dekat Mekkah -pada malam yang

${ }^{1}$ Siauddin Zardar, Kembali Ke Masa Depan Syariat Sebagai Metodologi Pemecahan Masalah (Yogyakarta: Serambi, 2005), h. 149 
menentukan 27 Ramadan 611: "bacalah dengan (menyebut) nama tuhanmu Yang menciptakan. Dia menciptakan manusia dari segumpal darah. Bacalah dan Tuhanmulah yang maha pemurah. Yang mengajar (manusia) dengan perantaraan pena. Dia mengajarkan kepada manusia apa yang tidak diketahui (Q.S. al Alaq: 15)". Sebuah kata kerja. Dan sebuah undangan maha luas untuk umat muslim mengembangkan pemikirannya, menuliskan, menyebarkan, mengkritik dan merekonstruksi pemikiran serta seluruh aktifitas spekulatif untuk mencapai ilmu pengetahuan.

Ketika rasulullah wafat, ia telah memastikan Quran telah menjadi sebuah kitab tertulis yang utuh sebagai teks panduan membangun tradisi mencari ilmu pengetahuan. Karena itu sejak nabi masih hidup dan beberapa abad setelah nabi wafat, periode ini menjadi periode gemilang dalam tradisi pemikiran dan perkembangan filsafat dan ilmu pengetahuan serta peradaban muslim. Di wilayahwilayah muslim, sejak abad 9 masehi telah ditemukan sebuah model penyelenggaraan pembelajaran revolusioner yang mendorong lahirnya ilmuwan, pemikir, dan cerdik cendekia: madrasah. Di wilayah-wilayah muslim yang maju, telah berkembang berbagai perpustakaan dengan koleksi ribuan buku, telah lahir pula pekerjaan baru akibat kebutuhan akan bahan bacaan di dunia muslim secara luas yakni warraqqin, para penyalin buku, dan seterusnya. Mustahil peradabah semaju ini, di era klasik Islam, yang diisi nama-nama tersohor seperti Ibnu Sina, Al Kindi, Al Farabi, Al Biruni, Ibnu Rusyd, dll sebagai peradaan yang tidak ditopang oleh sistem kefilsafatan yang maju. Karena itu, banyak pengamat menyatakan, periode ini adalah periode yang dibangun di atas pemikiran para filosof.

Artikel ini secara umum ingin menelisik bagaimana dunia intelektual berkembang di era klasik Islam dan apa kontribusinya atas ilmu pengetahuan dunia saat ini. Dari maksud tersebut itulah dirunut penjelasan mengenai apa respon awal umat Islam atas tradisi klasik ilmu pengetahuan dunia (terutama yunani), aktifitas apa saja yang dilakukan oleh para filsuf dan ilmuan muslim dan bagaimana kontak mereka dengan peradaban Eropa yang kemudian memicu transmisi ilmu pengetahun dari yunani, aleksandria, persia menuju peradaban klasik Islam dan kemudian menuju peradaban Eropa.

\section{Kapan Periode Klasik Barat dan Periode Klasik Islam?}

Ada dua periode berbeda meskipun sama-sama memiliki kata "klasik" dalam penjelasannya. Dua peride tersebut adalah periode Yunani Klasik dan periode Islam Klasik. Periode Yunani klasik berlangsung sekitar abad keenam hingga abad keempat sebelum masehi di Yunani. Dalam periode ini tersebut namanama yang paling menonjol karya-karya klasiknya. Mohammad Hatta (2006) dalam bukunya Alam Pikiran Yunani menyebutkan periode ini didominasi oleh pemikiran Sokrates, Aristoteles dan Plato. Ketiganya memilik pemikiran yang kompleks yang masih dirujuk hingga kini untuk sejumlah besar bidang ilmu, terutama ilmu sosial, hukum dan tata pemerintahan serta filsafat. Era ini disebut klasik karena sejumlah pemikirannya memiliki relevansi bagi pengembangan ilmu pengetahuan kini. 
Periode yang lain adalah periode Islam klasik yang berlangsung setelah nabi wafat hingga sekitar abad ke-13 masehi. Periode ini tidak selalu tetap mengenai angka tahun tersebut, tetapi para pemikir seringkali merujuk angka tahun tersebut. Periodisasi Islam seringkali merujuk pada periodisasi yang disusun oleh Harun Nasution. Menurutnya periode klasik diperhitungkan sejak wafatnya nabi hingga akhir tahun 1250 masehi, yaitu antara 650-1250 M. Periode selanjutnya disebut periode pertengahan yakni dari tahun 1250-1800 M. Sedangkan periode Islam modern diperhitungkan sejak tahun 1800 dan selanjutnya sampai sekarang. ${ }^{2}$ dalam pandangan Saleh Putuhena era klasik Islam berlangsung di antara abad VII hingga abad XIII Masehi. Periode ini dijuluki the golden age of Islam ${ }^{3}$.

Periodisasi semacam ini sebenarnya memiliki masalah yang tidak sedikit. Supriyatna misalnya mempersoalkan hal ini: "Istilah Islam Klasik membuka peluang untuk diperdebatkan: sejak kapan? Penulis barat mengidentikkan abad ke 7 sampai abad 12/13 M sebagai zaman kegelapan (dark age), sementara penulis muslim mengidentikkannya dengan masa keemasan (al-ashr al dzahabiy) ${ }^{4}$. Memang sejarah berbanding terbalik. Ketika dunia barat telah melewati periode klasik pada akhir periode sebelum masehi dan memasuki era pertengahan, beberapa abad setelahnya fajar Islam mulai bangkit dan memperbaiki sistem kebudayaannya hingga mencapai masa keemasan. Disinilah letak krusial peran Islam dalam transformasi pengetahuan Eropa. Pada periode klasik ini Islam mengalami perkembangan dan kemajuan dengan pesat dalam berbagai bidang seperti pemerintahan, budaya dan pendidikan Islam. Pendidikan Islam berkembang dari madnah ke damaskus, kemudian ke bagdad dan cordova. Pada kurun tersebut telah lahir ulama-ulama dan ilmuan-ilmuan besar dalam berbagai disiplin ilmu. Antara tahun 700-1200 M Islam memiliki kekuatan dalam bidang pemerintahan dan perkembangan sastra, sains, kedokteran dan filsafat maju dengan pesat. Sementara di dunia barat masih tertinggal. ${ }^{5}$

Periode klasik ini dalam catatn banyak sarjana memang sebuah periode yang gemilang. Karena gilang gemilangnya periode ini, seorang sarjana terkemuka dan juga seorang muslim yang mengajar di universitas London pada imperial college pernah mengatakan: " bahwa antara tahunn 750-1200 M ilmu pengetahuan atau sains terutama adalah milik orang-orang Islam"

\footnotetext{
${ }^{2}$ Abdul Munir Sunhaji Sistem dan metode pendidikan Islam klasik dalam Dr. Armai Arief, MA (editor) Sejarah Pertumbuhan dan perkembangan lembaga pendidikan Islam klasik (Bandung: Penerbit Angkasa, 2004) hal. 117. Masih dalam buku yang sama juga dikemukakan Supriyatna dalam Kurikulum Pendidikan Islam Klasik. h. 133

${ }^{3}$ Saleh Putuhena Ke Arah Rekonstruksi Sains Islam (ed) Nurman Said, Wahyuddin Halim dan Muhammad Sabri Sinergi Agama dan Sains Ikhtiar Membangun Pusat Peradaban Islam (Makassar: Aluddin University Press, 2005). h. 107

${ }^{4}$ Supriyatna Kurikulum Pendidikan Islam Klasik. h. 133

${ }^{5}$ Abdul Munir Sunhaji Sistem dan metode pendidikan Islam klasik dalam Dr. Armai Arief, MA (editor) Sejarah Pertumbuhan dan perkembangan lembaga pendidikan Islam klasik (Bandung: Penerbit Angkasa, 2004) h. 118

${ }^{6}$ Ashar Arsyad Sel Cemara Integrasi Dan Interkoneksi Sains Dan Ilmu Agama dalam (ed) Nurman Said, Wahyuddin Halim dan Muhammad Sabri Sinergi Agama dan Sains Ikhtiar Membangun Pusat Peradaban Islam (Makassar: Aluddin University Press, 2005) h. 95
} 
Apabila ditelusuri kota dan tahun kelahiran masing-masing imam mazhab, maka dapat diperkirakan bahwa antara kurun waktu sejak wafatnya rasul hingga diperkirakan akhir millenium pertama Hijriah, dikategorikan sebagai Islam klasik. Imam hanafi, lahir di kota kufah pada tahun 80 Hijriyah (699M); Imam Maliky, lahir di kota Madinah pada tahun 93 Hijriyah (712 M); imam syafi'iy, lahir di kota Ghuzah, palestina, pada tahun 150 Hijriyah $(780 \mathrm{M})$; dan terakhir imam hambali, lahir di kota bagdad, pada tahun 164 Hijriyah $(780 \mathrm{M}){ }^{7}$

\section{Respons Awal Atas Pemikiran Yunani}

Perkembangan pemikiran yang tumbuh karena banyak menimba dari peradaban Yunani klasik sungguh tumbuh amat mengejutkan. Sebuah spirit besar untuk menyambut sebuah kerangka epistemologi, sistem berfikir, sistem falsifikasi yang baru sedang tumbuh-tumbuhnya. Tercatat sejumlah ilmuwan, filosof dan sarjana muslim menerjemahkan, memberi notasi, menuliskan semacam critical review atas karya-karya yunani klasik milik Sokrates, Aristoteles dan Plato.

Meskipun demikian, respons atas pencerapan karya-karya klasik dari yunani sebenarnya tidaklah berjalan terlalu mulus. Disana sini ada kritik dan penolakan atas sistem berfikir, logika dan konsep filsafat yang dibawa oleh tokohtokoh yunani melalui karya-karyanya. Seorang guru besar filsafat dari liverpool john mooris university, Oliver Leaman, mencatat bahwa ada penolakan di tahaptahap awal inkorporasi pemikiran filsafat yunani ke dalam peradaban muslim. Oliver Leaman Menulis: "Keberatan utama untuk menerima prinsip-prinsip dan tekhnik-tekhnik pokok filsafat yunani berasal dari anggapan bahwa tindakan itu bisa berarti bahwa ilmu-ilmu Islam tidak sanggup menangani persoalan teoritis sehingga dirasakan perlunya membawa metodologi dari kebudayaan yang sangat berbeda dan muncul sebelum Islam. Mungkin tidak terlalu masalah kalau kebudayaan itu bersifat monoteistik. Dalam kenyataannya, kebudayaan yunani sering bertolak belakang (dengan agama-agama monoteistik). Ia mampu menghasilkan teknik-teknik teoritis yang mengesankan tanpa bantuan wahyu mana pun". 8

"Para penentang pemikiran Yunani mengajukan dua keberatan yang masuk akal atas penggunaan logika. Pertama, lebih daripada sekedar alat,logika dapat diterapkan pada sembarang bahasa. Kedua, sarana paling efektif untuk mengkaji isu-isu konseptual tentang suatu kebudayaan adalah yang berasal dari kebudayaan itu sendiri, bukan sesuatu yang diimpor dari yang lain. Hal ini tampak seperti tanggapan reaksioner dan xenofobik terhadap filsafat baru", tambah Leaman.

Bahkan penolakan itu lebih dari sekedar penolakan xenofobik seperti dikemukakan di atas. Penolakan lebih mendasar dan tajam juga dikemukakan oleh pengkritik pemikiran filsafat yang amat tersohor dalam pemikiran Islam, yakni Al

\footnotetext{
${ }^{7}$ Abdul Munir Sunhaji Sistem Dan Metode Pendidikan Islam Klasik dalam Dr. Armai Arief, MA (editor) Sejarah Pertumbuhan Dan Perkembangan Lembaga Pendidikan Islam Klasik (Bandung: Penerbit Angkasa, 2004) h. 118

${ }^{8}$ Oliver Leaman Pengantar Filsafat Islam Sebuah Pendekatan Tematis (Bandung: Mizan, 2002) h. 24
} 
Gazali. Penolakan utama al Gazali adalah "anggapan bahwa filsafat telah melampaui wewenangnya". 9 Dalam karya monumentalnya, tahafut Al-Falasifah (kerancuan para Filosof) mengkritik filsafat yang dikembangkan oleh Ibnu Sina. Dia berpendapat bahwa "dalam banyak hal, para filosof mengajukan teori-teori yang mencerminkan kekafiran, bukan sekedar bid'ah, yakni teori-teori yang berlawanan dengan asas-asas Islam, dan bukan sekedar penambahan atau penafsiran ulang"10.

Jadi melihat penjelasan di atas, filsafat diterima sebagai sebuah bentuk baru pemikiran dalam kebudayaan Islam tidak selalu dengan kondisi yang mulus tanpa rintangan. Akan tetapi sebaliknya, kondisinya malah banyak menghadapi ujian serius dari para filosof dan pemikir muslim sendiri. Meskipun demikian girah dasar di abad klasik memperlihatkan kemenangan orang-orang yang cenderung menerima dan mencerap pendekatan baru tersebut.

Dari penjelasan yang dikemukakan di atas terdapat dua respons utama peradaban muslim. Pada sisi pertama, ada goongan mereka yang menerima dengan terbuka, melakukan penerjemahan dengan aktif, menuliskan anotasi dan catatan kritis atas karya yunani. Termasuk di antara kelompok ini misalnya Al-Kindi, Ibnu Sina, Ibnu Rusyd, dll. Sementara di kutub yang lain, kelompok muslim yang menolak filsafat yunani masuk ke dalam sistem berfikir kaum muslim. Termasuk di antara kelompok ini yang paling menonjol adalah Al-Gazali, Abu Al Baraqat, Al-Bagdadi dan Fakhr Al-Din Al-Razi ${ }^{11}$.

Selain itu, ada juga hambatan bahasa. Sebagimana pada waktu itu bahasa arab belumlah tersebar sebagimana setelah 2 abad penyebaran Islam berlangsung. Maka ada masa dimana persoalan kesatuan bahasa juga menjadi masalah, terutama dalam konteks penerjemahan konsep-konsep filsafat yunani. Menurut catatn taqi Misbah Yazdi: " Pada mulanya, tiadanya bahasa bersamadan peristilahan tekhnis yang bisa disepakati para penerjemah dan ketidakcocokan asas-asas filsafat timur dan barat, menyukarkan pengajaran filsafat. Meski ini berlangsung tidak begitu lama hingga muncul jenius-jenius seperti Abu Nashr AL Farabi dan Ibnu Sina.”

\section{Perkembangan Pemikiran Islam Klasik}

Pemikiran Islam klasik, sebagaimana telah diungkapkan di atas, adalah periode setelah wafatnya rasulullah Muhammad SAW hingga tahun $1250 \mathrm{M}$. Dalam periode ini sejumlah pencapaian menonjol telah dlakukan. Pada mulanya kelahiran perintah untuk mencari ilmu pengetahuan; kemudian penerjemahan karya-karya ilmu pengetahuan klasik, dan penyebaran melalui pengajaran di madrasah-madrasah yang tersebar di kota-kota besar Islam. Berikut elaborasinya lebih lanjut:

\section{Mulai dari Perintah Al-Qur'an dan tuntunan Rasulullah}

\footnotetext{
${ }^{9}$ Oliver Leaman, Pengantar Filsafat Islam Sebuah Pendekatan Tematis. h. 27

${ }^{10}$ Oliver Leaman, Pengantar Filsafat Islam Sebuah Pendekatan Tematis. h.. 27

${ }^{11}$ Muhammad Taqi Mishbah Yazdi Buku Daras Filsafat Islam (Bandung: Mizan, 2003) h. 9
} 
Sejak awal, ketika pertama turun di gurun makkah, perintah awal ajaran agama baru ini, ajaran Islam adalah Iqra. Sebuah kata kerja. Sebuah ungkapan dan undangn untuk mencari pengetahuan secara luas. Ajaran dasar agama baru ini adalah penghargaan terhadap Ilmu pengetahuan. Karena itu, dengan mudah kebudayaan mereka akrab dengan tradisi-tradisi Ilmu pengetahuan paling maju di belahan dunia seperti Persia, India, Aleksandria dan tentu Yunani, kampung halaman para filsuf klasik.

Nabi kemudian menyerukan untuk ummatnya, ummat yang baru lahir itu, mencari pengetahun "sejak dari buaian sampai ke liang lahat"; bahkan d perintahkan mencari ilmu "walau sampai ke neger Cina (tempat yang cukup jauh dari mekkah, waktu itu). Berikut ungkapan, Taqi Misbah Yazdi, seorang filosof Iran kontemporer mengenai perkembangan awal peradaban muslim yang dmulai dari seruan nabi suci mereka: "Berkat seruan Nabi dan para penerusnya yang suci, kaum muslim mulai mempelajari beragam ilmu dan menerjemahkan warisan Yunani, Roma dan persia ke dalam bahasa arab. Unsur-unsur bergunanya mereka serap, dengan menambahkan padanya hasil-hasil penelitian mereka sendiri. Dan dalam sebagian besar lapangan, mereka berhasil menyumbangkan berbagai temuan, seperti aljabar, trigonometri, astronomi, ilmu perspektif, fisika dan kimia" (Taqi Misbah Yazdi: 8).

\section{Penerjemahan Karya-Karya Klasik}

Kerjaan mula-mula, terutama pada periode-periode awal Islam, adalah kerjaan penerjemahan karyakarya besar klasik hampir seluruh peradaban besar: Yunani, Persia, roma, Aleksandria bahkan India. Gerakan ini serupa gerakan intelektual besar-besaran dengan spirit yang tak habis-habisnya. Sebuah gambaran yang amat umum dtemukan dalam penjelasan mengenai gerakan awal penerjemahan yang dilakukan oleh kebudayaan Islam adalah "tradisi intelektualisme ini diawali dengan gerakan penerjemahan buku-buku yunani dan bangsa-bangsa lainnya ke dalam bahasa Arab yang berpusat di Bait al-Hikmah di Bagdad. Ilmu-ilmu yang dicakup gerakan penerjemahan ini adalah ilmu kedokteran, matematika, fisika, mekanika, botanika, optika, atronomi di samping filsafat dan logika. Yang diterjemahkan adalah karangan-karangan Galinos, Hipokratos, Ptolomeus, Euclid, Plato, Aristoteles, Sokrates, D1l’" ${ }^{12}$

Saleh Putuhena meringkas pandangannya mengenai era klasik Islam: "Selama seabad (750-850) telah terjadi proses penerjemahan pengetahuan dalam bahasa Yunani, bahasa Ibrani, bahasa Persia dan bahasa-bahasa India ke dalam bahasa Arab. Selain kegiatan penerjemahan, para ilmuwan muslim berusaha mengadakan adaptasi terhadap ilmu pengetahuan asing itu dan menyusun kitab sendiri, terutama setelah masa terjemahan. Kegiatan penulisan ilmu-ilmu umum berlangsung sampai abad ke XI"

Gerakan penerjemahan awal ini juga makin meluas seiring dengan kontakkontak intelektual Islam dan wilayah-wilayah Islam yang juga makin meluas jauh

${ }^{12}$ Muhammad Sabri, Muhammad Saleh Tadjuddin dan Wahyuddin Halim, Buku Daras Filsafat Ilmu (Makassar: UIN Alauddin, tt) h. 28. 
ke wilayah-wilayah baru yang dulu belum dijangkau. Pertumbuhan-pertumbuhan pusat-pusat pembelajaran dan perpustakaan juga memperbesar jangkauan gerakan penerjemahan ini. Taqi Misbah menggambarkan bahwa "Seiring dengan meluasnya wilayah pemerintahan Islam dan membesarnya kecenderungan berbagai kalangan kepada agama yang menghidupkan ini, sekian banyak pusat pembelajaran dunia termasuk dalam wilayah Islam. Terdapat pertukaran gagasan di antara para sarjana dan buku di antara berbagai perpustakaan dunia dalam skala besar dan penerjemahan dari beragam bahasa (India, Persia, Yunani, Latin, Suryani, Ibrani dan sebagainya) ke dalam bahasa arab yang secara de facto telah menjadi bahasa internasional umat muslim. Inilah yang lantas mempercepat laju pertumbuhan filsafat, beragam sains dan kesenian. Sekian banyak buku para filosof yunani dan alxandria serta para filosof dari pusat-pusat pembelajaran yang punya reputasi dipindahkan ke Arab" (Yazdi: 9).

\section{Penyebaran dan Pengajaran melalui Madrasah}

Fase berikut dari perkembangan dan perluasan jangkauan kebudayaan Islam yang makin kuat dan makin kaya akibat pertumbuhan pusat-pusat kebudayaan, perpustakaan dan madrasah seperti yang ada Bagdad, Mesir dan Makkah juga Andalusia. Kemajuan-kemajuan ini kemudian mengundang para pelajar, tidak hanya dari kalangan muslim, tai juga terbuka untuk kalangan barat kristen. Proses penyebaran gagasan dan transmisi ilmu pengetahuan Islam ke dunia barat ini digambarkan dengan cukup menarik oleh Azhar Arsyad: "Tahun 1200$1300 \mathrm{M}$ berdatanganlah orang-orang barat untuk belajar di Universitas-universita Islam, yang antara lain berada di Cordova dan toledo dalam kawasan Spanyol, untuk mempelajari sains dari orang-orang Islam. Nama-nama mereka seperti Chester, Sacrobosco, De Toledo, De Servilla dan De Cremona menyalin bukubuku ilmu pengetahuan tulisan tokoh-tokoh sains Islam, seperti jabir, AL Hasan, Al Battani, Al-Razi, al-Farabi, al-Kindi dan sebagainya dan mereka juga menyalin buku-buku Applonius, Arhcimedes, Euclidas, Hippocrates dan lain sebagainya yang sebelumnya sudah diterjemahkan ke dalam bahasa arab. Jadi orang-orang Eropa mengenal buku-buku itu bukan dari bahasa aslinya, yaitu Yunani, melainkan melalui terjemahan bahasa arab"13. Sebagian dari ara pelajar-pelajar awal Eropa adalah mereka yang diajar di madrasah-madrasah muslim di berbagai kota besar Islam di sekitar tahun 900-12000an. Tentang bagaimana model dan praktek transmisi kemajuan pengetahuan Islam menuju peradaban barat digambarkan pada bagian di bawah ini:

\section{Pengaruh Pemikiran Islam Klasik terhadap Pengetahuan Barat Modern}

Pemikiran Islam klasik berpengaruh pada banyak sisi pertumbuhan pemikiran modern dunia barat. Pertama-tama, seperti telah dulang-ulang di atas, penerjemahan berbagai buku klasik adalah peran cukup besar peradaban muslim, kemudian teknologi pembuatan kertas yang mendorong penulisan ilmu

\footnotetext{
${ }^{13}$ Azhar Arsyad h. 97
} 
pengetahuan ke dalam manuskrip-manuskrip yang lebih tahan lama, menemukan sebuah model penyelenggaran pembelajaran berupa madrasah yang kemudian ditiru oleh orang-orang barat menjadi seminari-seminari hingga sampai kebudayaan Islam telah melahirkan pemikir-pemikir besar yang penting dan tak bisa dihilangkan dari sejarah perkembangan Eropa. Penjelasan di bawah ini merupakan elaborasi dari proposisi-proposisi pokok di atas:

\section{Menjadi mata rantai penyambung: Proses menerjemah dan memberi tanggapan}

Selama seabad (750-850) telah terjadi proses penerjemahan pengetahuan dalam bahasa Yunani, bahasa Ibrani, bahasa Persia dan bahasa-bahasa India ke dalam bahasa Arab. Selain kegiatan penerjemahan, para ilmuwan muslim berusaha mengadakan adaptasi terhadap ilmu pengetahuan asing itu dan menyusun kitab sendiri, terutama setelah masa terjemahan. Kegiatan penulisan ilmu-ilmu umum berlangsung sampai abad ke XI. Adalah suatu ironi bahwa sesudah abad ke XI, karya-karya terjemahan dalam bahasa arab itu diterjemahkan kembali ke dlam bahasa latin dan bahasa ibrani. Maka jadilah ilmu pengetahuan yang semula merupakan kekayaan intelektual sangat berharga milik umat muslim di bawa ke barat".

Bagian ini sudah sedemikian sering diulang-ulang oleh sejarawan pemikiran mengenai penerjemahan dan kemudian menjadi bentuk sampainya 'pengetahuan klasik' ke tangan kebudayaan 'Eropa modern. Tetapi bukan sekedar menerjemahkan, para pemikir muslim juga memberi catatan, notasi, memberi kritik dan menyusun sendiri argumennya. Hal ini seperti digambarkan Muhammad Sabri, Dkk bahwa: "dalam mengakses ilmu dan peradaban Yunani, para cendekiawan muslim tidak sekedar mencatat dan menterjemahkan karya tersebut, melainkan juga mengomentari, memberi notasi dan mengembangkannya ke dalam hasil-hasil penelusuran mereka sendiri. Sehingga transmisi pengetahuan dari [eradaban yunani ke dunia Islam di sini tidaklah dalam pengertian kinematik semata, tetapi justru menciptakan paradigma keilmuan yang khas dan tipikal muslim, dan dengan begitu mereka berhasil dalam memulai tradisi ilmiah yang baru serta dalam bahasa yang baru pula" 14

\section{Penemuan Kertas, Penulisan Buku dan penyebarannya serta Pengembangan Situs-situs Pengetahuan}

Hal yang tidak begitu banyak disorot oleh para sarjana adalah bahwa kebudayaan Islamlah yang menyebabkan kertas bisa diproduksi secara massal. Berawal dari pelajaran orang Samarkand terhadap kertas dari linen yang dibawa oleh orang Cina lalu kemudian dibuat sendiri dengan tekhnologi yang dikembangkan sendiri oleh orang-orang muslim. Wal hasil jadilah temuan besar yang amat bermanfaat menjadi medium transmisi pemikiran dalam bentuk bukubuku yang terdiri dari lembaran-lembaran kertas. Karena itulah industri kertas pertama kali lahir di wilayah-wilayah muslim. Berikut gambaran Siauddin Zardar mengenai hal tersebut: "Industri kertas menyebar dari Samarkand. Percetakan kertas pertama di Baghdad didirikan tahun 793 selama pemerintahan khalifah

\footnotetext{
${ }^{14}$ Muhammad Sabri, Muhammad Saleh Tadjuddin dan Wahyuddin Halim, Buku Daras Filsafat Ilmu (Makassar: UIN Alauddin, tt) h. 29.
} 
Abbasiyah terkemuka, Harun AL Rasyid (W. 809). Tak lama kemudian, pakrikpabrik kertas segera didirikan di damaskus, tiberia, tripoli, kairo, Fez, dan sicilia Islam, Jativa dan valensia di spanyol Islam dan berbagai belahan dari dunia Islam lainnya. Dalam beberapa dekade, seorang wazir dinasti abbasiyah, Ja'far ibn yahya mengganti perkamen menjad kertas di kantor-kantor pemerintahan. Bahkan pada abad ke-10, terdapat pabrik-pabrik kertas yang mengapung di tigris, dan kertas menjadi sedemikian populer. Pabrik kertas pertama di Eropa baru dibangun tahun 1276 di fabrino, italia dan pabrik berikutnya di Nurenberg, jerman, tahun 1390 M".

Saking berkembangnya peradaban yang berakar pada kertas dan aktifitas literasi, di kota-kota utama Islam telah berkembang perpustakaan-perpustakaan besar dengan koleksi yang amat kaya. Untuk hal itu, "AL Ya'qubi saja, seorang sarjana muslim terkenal pada akhir abad ke 9, mencatat lebih dari 100 toko buku di waddah, pinggiran kota Baghdad". ${ }^{15}$

Berikut gambaran Saleh Putuhena mengenai kondisi perkembangan ilmu pengetahuan karena perkembangn buku dan perpustakaan serta pusat-pusat studi di wilayah-ilayah muslim: "Pusat-pusat studi berupa perpustakaan yang didirikan oleh pemerintah, baik untuk kegiatan belajar maupun menulis seperti Baitul Hikmah di Baghdad, Darul Hikmah di Kairo dan kemudian masjid Cordova di spanyol, berfungsi sebagai universitas riset dalam terminologi modern. Mereka juga mendirikan laboratorium untuk mengadakan riset dalam rangka pengembangan sains dan tekhnologi. Semula ilmu pengetahuan itu belum dikelompokkan. Di kawasan timur dunia Islam (asia barat dan mesir) dikembangkan ilmu-ilmu seperti kedokteran, filsafat, kimia, matematika dan ilmu bumi. Sementara di dunia Islam barat (spanyol) dikembangkan ilmu-ilmu kedokteran, astronomi, matematika, sejarah, sastra dan ilmu bumi di samping studi keagamaan (2005: 108-109)".

\section{Mengenalkan model sistem pendidikan dan pengelolaan lembaga pendidikan: madrasah}

Madrasah adalah salah satu revolusi dalam penyelenggaraan pendidikan dan pengelolan lembaga pendidikan yang dilakukan oleh umat Islam di era klasik. Lembaga pendidikan madrasah adalah kelanjutan dari lembaga pendidika dalam bentuk masjid. Karena banyaknya murid-murid yang datang dari luar kota untuk belajar di mesjid, menuntut adanya tempat tinggal yang disebut dengan Khansemacam asrama. Sehingga terjadi perubahan dari mesjid ke mesjid khan. Selanjutnya dari mesjid khan ke madrasah. Ada yang menyebutkan bahwa pendiri pertama sebuah lembaga madrasah adalah Nizam al-Mulk seorang persia, dari Thus. Karena itu kebanyakan madarasah yang didirikannya menisbatkan namanya. Jadilah madrasah itu dikenal dengan nama madrasah Nisamiyah pada tahun 1067 M. Nizam mendirikan perguruan tinggi besar di Bagdad yang diberi nama Nizamiyah. Bukan hanya di Bagdad, tetapi Nizam juga mendirikan madrasah di Balkh, Nisapur, Heart, Isfahan, Basrah, Merw, Amul dan Mosul. Yang paling terkenal di antara semuanya adalah madrasah Nizamiyah di bagdad. Dalam

${ }^{15}$ Siauddin Zardar, Kembali ke Masa depan Syariat Sebagai Metodologi Pemecahan Masalah (Yogyakarta: Serambi, 2005) h. 159 
pembangunan madrasah, Nizam al Mulk menyediakan wakaf untuk membiayai seorang mudarris, seorang imam, dan juga mahasiswanya menerima beasiswa dan fasilitas asrama ${ }^{16}$.

Sekitar satu abad setelah berdiri madrasah Nizamiyah, di Haramayn, Makkah dan Madinah, didirikan madrasah al-Ursufiyah (1196 M), di selatan Masjidil Haram. Di periode tersebut, selanjutnya berdiri ada 20 madrasah di Makkah, menurut catatan Naji Ma'ruf ${ }^{17}$. Selain madrasah tersebut, ada juga madrasah al-Azhar di Mesir yang juga merupakan universitas tertua di dunia yang menjadi contoh bagi universitas-universitas di Eropa pada abad-abad selanjutnya. ${ }^{18}$

Menurut beberapa kalangan, masjid di Kordova, yang dijadikan madrasah, kemudian dikenal dengan Universitas Kordoba banyak menyertakan orang-orang nasrani dari Eropa - terutama paruh pertama abad ke 11- guna mengikuti studi pada universitas dimaksud. Belakangan, universitas ini menjadi salah satu tempat terpenting dalam transmisi sains dari dunia Islam ke dunia barat. ${ }^{19}$

\section{Mewariskan Pemikir-Pemikir Besar}

Selain apa yang telah dikemukakan di atas, warisan terpenting dari kebudayaan Islam klasik yang amat maju itu adalah sejumlah teori dan pemikirpemikir ilmupengetahuan baru. Azhar Arsyad Memberikan contoh-contoh tokoh klasik pemikiran Islam yang menonjol dan menjadi sumbarang umat Islam untuk dunia. Mereka adalah nama-nama besar yang malang melintang dalam literatur barat dengan nama yang dilatinkan. Mereka diberi nama latin biar lebih akrab digunakan oleh lidah mereka. Tetapi sejarah kemudian tetap bisa mengidentifikasi bahwa mereka semua adalah filsuf-filsuf muslim. Berikut ulasan biorafi singkat beberapa tokoh yang ditunjukkan Ashar Arsyad ${ }^{20}$ :

"Sebutlah misalnya Jabir Ibnu Hayyan. Orang-orang Eropa menamakannya: Gebert, yang hidup antara tahun 721-815 M. Dia adalah seorang tokoh Islam pertama yang mempelajari dan mengembangkan Alchemi di dunia Islam. Ilmu ini kemudian berkembang dan kita kenal sebagai ilmu kimia. Bidang keahliannya yang lain adalah bidang logika, filosofi, kedokteran, fisika mekanika, dan sebagainya. Nyata bahwa jabir merupakan seorang yang mempunyai pengetahuan yang luas. Dia adalah seorang muslim yang tekun dan ikhlas, di samping dia mempelajari ilmu-ilmu kimia, mekanika, fisika, kedokteran dan sebagainya. Misal yang lain adalah Abu Jusuf Ya'qub Ibnu Ishaq Al-Kindi

\footnotetext{
${ }^{16}$ Raihani Madrasah Nisamiyahdalam Sejarah Pertumbuhan Dan Perkembangan Lembaga Pendidikan Islam Klasik (Bandung: Penerbit angkasa, 2004) h. 64-67

${ }^{17}$ Muhammad Fadhil Madrasah Haramayn dalam Sejarah Pertumbuhan Dan Perkembangan Lembaga Pendidikan Islam Klasik (Bandung: Penerbit angkasa, 2004) h. 79

${ }^{18}$ Elwis Nazar Al-Azhar Bentuk Tipikal Madrasah Tinggidalam Sejarah Pertumbuhan Dan Perkembangan Lembaga Pendidikan Islam Klasik (Bandung: Penerbit angkasa, 2004) h. 89

${ }^{19}$ Muhammad Sabri, Muhammad Saleh tadjuddin dan wahyuddin Halim Buku Daras UIN Alauddin Makassar Filsafat Ilmu (Makassar: UIN alauddin, tt) h. 29.

${ }^{20}$ Ashar Arsyad Sel Cemara Integrasi Dan Interkoneksi Sains Dan Ilmu Agama dalam (ed) Nurman Said, Wahyuddin Halim dan Muhammad Sabri, Sinergi Agama dan Sains Ikhtiar Membangun Pusat Peradaban Islam (Makassar: Aluddin University Press, 2005) h. 95-96.
} 
(801/815 M). D barat dia dikenal dengan nama Al-Kindus; memang sudah menjadi kebiasaan orang barat dahulu untuk melatinkan nama-nama orang terkemuka, sehingga kadang-kadang orang tidak mengetahui apakah ia orang Islam atau bukan. Al-Kindi adalah seorang filosof muslim dan ilmuwan dalam bidang filosofi, matematika, logika, sampai kepada musik dan ilmu kedokteran. Tokoh lan yang bisa kita temukan adalah Muhammad Ibnu Musa Al Khawarismi (wafat $863 \mathrm{M}$ ). Orang Eropa menyebutnya Algorism. Nama itu kemudian dipakai oleh orangorang barat sebagai ilmu hitung (algoritma). Karena apa? Bukunya yang terkenal berjudul Al Jaber wa al-Muqabalah yang kemudian disalin oleh orang-orang barat dan sampai sekarang ilmu itu kita kenal dengan nama aljabar".

"Begitu pula dengan muhammad Ibnu Zakaria Al-Razi (865-965 M). Nama latinnya adalah Razes. Dia adalah seorang dokter klinis yang terbesar pada samannya. Bidang keahliannya adalah Alchemi yang sekarang kita kenal dengan ilmu kimia dan kedokteran", lanjuta Azhar Arsyad. "Seterusnya, kita tidak bisa melupakanAbu Nashr AL Farabi. Orang barat menyebutnya Alfarabius. Dia hidup antara tahun 870-900. Dia merupakan tokoh Islam yang pertama dalam bidang logika. Al-Farabi mengembangkan dan mempelajari ilmu fisika, matematika, etika, filosofi dan politik serta yang lainnya".

"Yang sangat terkenal dari mereka adalah Abu Ali Al Husein Ibnu Sina yang dilatinkan dengan nama Avicenna, hidup antara tahun 980-1037 M. Dia adalah seorang ilmuwan dan filosof yang besar pada waktu itu, hingga kepadanya diberikan julukan Syeikh Al-Rais. Memang Ibnu Sina orang yang istimewa. Pada usia 10 tahun dia sudah hafal Al-Quran, kemudian pada usia delapan belas tahun dia sudah menguasai semua ilmu yang pada waktu itu ada. Bidang keahliannya adalah: ilmu fisika, geologi, ilmu kedokteran, mineralogi dan sebagainya. Pakar alim lainnya adalah Abu Ali Al-Hasan Ibnu Haitham. Dia lebih dikenal dengan nama latin al-Hazen yang hidup antara tahun 965-1039 M. Ia seorang ahli fisika yang ternama dan seorang ahli fisika Islam yang pertama. Kecuali ilmu fisika dia juga mengembangkan ilmu-ilmu lan seperti matematika, atronomi, dan juga ilmu kedokkteran".

"Kemudian Abu'l Walid Muhammad Ibnu Rusyd yang dikenal di barat dengan Averroes. Tokoh ini hidup antara tahun 1126-1198 M. Ibnu Rusyd dalam pandangan orang barat adalah seorang tokoh yang besar sehubungan dengan aliran rasionalismeyang di samping astronomi dan lain-lain yang diikutinya dalam bidang filsafat".

"Tokoh-tokoh tersebut juga ditambahkan oleh Saleh Putuhena dalam bidang sosial adalah Yaqut Ibn Abdullah al Hamawi (1179-1229 M) dan Abdullah ibn Abdullah ibn Yusuf Ibn Batutah (1304-1377) yang berasal dari maroko ini telah membukukan pengalaman perjalanannya ke beberapa tempat termasuk Nusantara dengan judul Rihlah Ibn Bhatutah. Dalam bidang sejarah bisa 
disebutkan seperti Muhammad Ibnu Ishaq (w. 768) dan Abdul Malik Ibnu Hisyam (w. 834). Dan lain sebagainya",21.

\section{Tahapan Trasmisi Pengetahuan Islam Ke Barat-Kristen Abad Pertengahan}

Dalam sebuah ringkasan dari proses transmisi pengetahuan Islam hingga sampai kepada kebudayaan barat, Muhammad Sabri, dkk menjelaskan proses tiga tahap transmisi ${ }^{22}$. Berikut rinciannya:

Tahap pertama, kelompok sarjana (barat) mengunjungi wilayah-wilayah Muslim untuk melakukan kajian-kajian pribadi. Constantinus Africanus (1087 M) dan Adehard (1142 M) dari inggris dapat disebut sebagai perintisnya. Belakangan banyak pelajar dari itali, spanyol dan prancis selatan menghadiri seminari-seminari muslim untuk belajar matematika, filsafat, kedokteran, kosmologi, dan lain-lain. Dalam waktu yang tidak lama, mereka telah menjadi kandidat professor di universitas-universitas pertama di barat, yang dibangun dengan mencontoh seminari-seminari muslim tersebut.

Tahap kedua, bermula dari pendirian universitas-universitas pertama di barat. Gaya arsitektur, kurikulum, metode dan pengajaran universitas-universitas ini sama dengan yang ada pada seminari-seminari muslim. Untuk pertama kalinya, seminari Salermo didirikan di Napoli oleh raja Frederick dari sicilia. Di Sicilia, buku-buku aristoteles diterjemahkan ke dalam bahasa latin dari terjemahan bahasa arabnya, untuk kemudian dibawa ke Italia. Pada saat yang sama, universitasuniversitas penting juga didirikan di Pandua, Toulouse dan Belakangan di Leon.

Akhirnya, tahap ketiga, sains muslim ditransmisi ke Prancis dan wilayahwilayah barat lewat Itali. Seminari-seminari di Bologna dan Montpellier didirikan pada awal abad ketigabelas. Baru beberapa saat universitas Paris dibuka. Sementara itu, sains barat ini tiba di Inggris dan Jerman, masing-masing lewat Universitas Oxford dan Koln, yang didirikan dengan pola yang sama.

\section{DAFTAR PUSTAKA}

\footnotetext{
${ }^{21}$ Saleh Putuhena Ke Arah Rekonstruksi Sains Islam (ed) Nurman Said, Wahyuddin Halim dan Muhammad Sabri Sinergi Agama dan Sains Ikhtiar Membangun Pusat Peradaban Islam (Makassar: Aluddin University Press, 2005), h. 108.

${ }^{22}$ Muhammad Sabri, Muhammad Saleh Tadjuddin dan Wahyuddin Halim, Buku Daras Filsafat Ilmu (Makassar: UIN Alauddin, tt) h. 31-32
} 
Abdullah, M. Amin. Falsafah Kalam. (Cet. II. Jogyakarta: Pustaka Pelajar), 1997. Muhammad Sabri, Muhammad Saleh Tadjuddin dan Wahyuddin Halim Buku Daras Filsafat Ilmu (Makassar: UIN alauddin, $\mathrm{tt}$ )

Atjeh, Abu Bakar, Sejarah Filsafat Islam, Semarang: CV. Ramadhani, 1968.

Al-Ahwany, Ahmad Fuad. Alfalsafatul Islamiyah. Cairo: Al-Makthabatus tsakafiyah, 1962. . Al Falsafatul Islamiyah. Dialih bahasakan oleh Sutardji Calsoun Bachri dengan judul Filsafat Islam. Cetakan I. Jakarta:" Pustaka Psnjimsas, 1985

Al Ghazali, Tahafaqtul Falasifah. Dialih bahasakan oleh Ahmadie Thaha dengan judul Tahafut Al Falasifah Kerancuan Para Filosof. Jakarta: Pustaka Panji mas, 1986.

Al Iraqy, Muhammad Athif. Al-Nas at Al-aqliyah Fil Falsafah Ibnu Rusyd. Mesir: Dar Maarif, 1968.

Al Attas, M. Naquib. Filsafat dan Praktik Pendidikan Islam. Catakan I. Bandung: Mizan, 2003.

Ahmad, H. Abu. Filsafrat Islam. Cetakan I. Semarang: CV. Toha Putra, 1982.

Bakker Sy, JWM. Sejarah Filsafat dalam Islam. Cetakan II. Jogyakarta: yayasan Kassinius, 1984

Dun-yaa, Sulaeman. Tahafut al Tahafut. Lil Qadhy Abi Al Walid Muhammad Ibnu Rusyd. Juz I. Cetakan III Mesir: Daar Al Maarif, 1969.

Hanafi, Ahmad. Pengantar Filsafat Islam, (Cet. III; Jakarta: Bulan Bintang), 1982.

Nasution, Harun. Filsafat dan Mistisime dalam Islam. Cetakan II. Jakarta: Bulan Bintang, 1978. Akal dan Wahyu dalam Islam. Jakarta: Universitas Indonesia, 1980.

Nasutioan. Harun. Islam Rasional (gagasan dan pemikiran). Bandung: Mizan, 1996.

Saleh Putuhena Ke Arah Rekonstruksi Sains Islam (ed) Nurman Said, Wahyuddin Halim dan Muhammad Sabri Sinergi Agama dan Sains Ikhtiar Membangun Pusat Peradaban Islam (Makassar: Aluddin University Press, 2005)

Yazdi, Muhammad Taqi Misbah. Buku Daras Filsafat Islam, Bandung: Mizan, 2003.

Supriyadi, Dedi. Pengantar Filsafat Islam (Konsep, Filsuf, dan Ajarannya). Bandung: CV. Pustaka Setia, 2009.

Ashar Arsyad, Sel Cemara Integrasi Dan Interkoneksi Sains Dan Ilmu Agama dalam (ed) Nurman Said, Wahyuddin Halim dan Muhammad Sabri Sinergi Agama dan Sains Ikhtiar Membangun Pusat Peradaban Islam (Makassar: Aluddin University Press, 2005)

Siauddin Zardar, Kembali Ke Masa Depan Syariat Sebagai Metodologi Pemecahan Masalah (Yogyakarta: Serambi, 2005) 